\title{
Penerapan Algoritma K-Means dalam Mengelompokkan Balita yang Mengalami Gizi Buruk Menurut Provinsi
}

\author{
Muhammad Dwi Chandra', Eka Irawan², Ilham Syahputra Saragih ${ }^{3}$, Agus Perdana Windarto ${ }^{4}$ \\ Dedi Suhendro 5 \\ 1,2,3,4,5 Jurusan Sistem Informasi, STIKOM Tunas Bangsa Pematangsiantar \\ ${ }^{1}$ muhammadchandra1998@gmail.com, ²eka.irawan@amiktunasbangsa.ac.id,3ilham@amiktunasbangsa.ac.id, \\ 4agus.perdana@amiktunasbangsa.ac.id, ${ }^{5}$ dedi.su@amiktunasbangsa.ac.id
}

Keywords:

K-Means Algorithm,

Toddler,

BPS,

Province,

Data Mining,

\begin{abstract}
The purpose of this study was to screen toddlers who were experiencing severe malnutrition according to province. Sources of research data used were obtained from the Ministry of Health of the Republic of Indonesia. The variables used are toddlers who experience malnutrition according to the Province. In this study using Data Mining Techniques using the K-means algorithm. It is expected that the results of this study can provide input to the central government to pay more attention to nutritional intake in infants, so as to increase the growth and development of toddlers in Indonesia. . And the data obtained by high clusters are 15 Provinsi yaitu (Aceh, Sumatera Utara, Nusa Tenggara Barat, Nusa Tenggara Timur, Kalimantan Barat, kalimantan Tengah, Kalimantan Selatan, Sulawesi Tengah, Sulawesi Selatan, Sulawesi Tenggara, Sulawesi Tenggara, Gorontalo, Sulawesi Barat, Papua Barat, Papua), dan cluster rendah ada 19 yaitu (Sumatera Barat, Riau, Jambi, Sumatera Selatan, Bengkulu, Lampung, Kep. Bangka Belitung, Kep. Riau, Dki Jakarta, Jawa Barat, Jawa Tengah, DI Yogyakarta, Jawa Timur, Banten, Bali, Kalimantan Timur, Kalimantan Utara, Sulawesi utara, Maluku Utara).
\end{abstract}

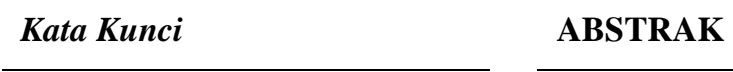

Algoritma K-Means,

Balita,

BPS,

Provinsi

Data Mining,

\begin{abstract}
Tujuan penelitian ini adalah untuk mencluctering balita yang mengalami gizi buruk menurut Provinsi. Sumber data penelitian yang digunakan diperoleh dari BPS. Adapun variabel yang digunakan adalah balita yang mengalami gizi buruk menurut Provinsi. Pada Penelitian ini menggunakan Teknik Data Mining dengan menggunakan algoritma $K$-means. Diharapkan hasil penelitian ini dapat memberikan masukan kepada pihak pemerintah pusat agar lebih memperhatikan asupan gizi pada balita, sehingga dapat meningkatkan pertumbuhan dan perkembangan balita yang ada di Indonesia. Dan data yang diperoleh cluster tinggi ada 15 Provinsi yaitu (Aceh, Sumatera Utara, Nusa Tenggara Barat, Nusa Tenggara Timur, Kalimantan Barat, kalimantan Tengah, Kalimantan Selatan, Sulawesi Tengah, Sulawesi Selatan, Sulawesi Tenggara, Sulawesi Tenggara, Gorontalo, Sulawesi Barat, Papua Barat, Papua), dan cluster rendah ada 19 yaitu (Sumatera Barat, Riau, Jambi, Sumatera Selatan, Bengkulu, Lampung, Kep. Bangka Belitung, Kep. Riau, Dki Jakarta, Jawa Barat, Jawa Tengah, DI Yogyakarta, Jawa Timur, Banten, Bali, Kalimantan Timur, Kalimantan Utara, Sulawesi utara, Maluku Utara).
\end{abstract}

\author{
Korespondensi Penulis: \\ Muhammad Dwi Chandra, \\ STIKOM Tunas Bangsa, \\ Jalan Sudirman Blok A No 1, 2, 3 Pematangsiantar \\ Telepon: +62 85667694581 \\ Email: muhammadchandra1998@gmail.com
}

\section{PENDAHULUAN}

Masa balita biasa sering dikatakan sebagai masa golden age atau masa keemasan karena masa pertumbuhan atau perkembangan seseorang di masa selanjutnya ditentukan pada saat balita. Pertumbuhan pada balita tidak hanya digunakan sebagai gambaran dalam bertambahnya ukuran anggota tubuh, tetapi juga digunakan sebagai gambaran 
mengenai kesinambungan antara asupan dan kebutuhan gizi [1]. Gizi merupakan salah satu asupan yang sangat penting bagi pertumbuhan balita karena gizi yang baik membuat balita tumbuh normal dan jika gizi yang diperoleh balita tersebut buruk maka bertumbuhan balita dapat terhambat.

Tidak semua balita di Indonesia mendapatkan gizi yang baik, Sehingga perlu adanya pengelompokkan untuk mengetahui wilayah mana yang balitanya masik kurang mendapatkan gizi baik, maka dari itu pemberian gizi harus ditingkatkan agar kebutuhan balita yang ada di Indonesia tentang gizi dapat terpeuhi dengan baik dan balita dapat berkembang dengan baik. Untuk mengetahui apakah balita tumbuh dan berkembang dengan baik adalah dengan cara melihat tumbuh kembang balita idealnya seperti apa. Kalau tinggi atau berat balita tidak ideal bisa dipastikan balita tersebut mengalami gizi buruk.

Pada penelitian ini, penulis akan membuat penelitian dengan mengelompokkan balita yang mengalami gizi buruk menurut Provinsi dengan menggunakan metode $k$-means. Adapun data yang diperoleh bersumber dari Badan Pusat Statistik (BPS). Dimana yang diperoleh adalah balita yang mengalami gizi buruk maenurut Provinsi.

Data mining adalah proses yang menggunakan teknik statistik, matematika, kecerdasan buatan, dan machine learning untuk mengekstraksi dan mengidentifikasi informasi yang bermanfaat dan pengetahuan yang terkait dari database yang besar [2]. Metode data mining memiliki beberapa bagian, salah satunya adalah clustering. Clustering memeliki berbagai metode yang digunakan untuk mengelompokkan salah satunya adalah metode $K$-means. $K$ Means merupakan salah satu metode data clustering non hirarki yang berusaha mempartisi data yang ada ke dalam bentuk satu atau lebih cluster/kelompok.

Berdasarkan permasalahan yang telah diuraikan diatas, penulis berinisiatif melakukan penelitian untuk mengelompokkan balita yang mengalami gizi buruk menurut Provinsi menggunakan data mining algoritma k-means clustering. Dengan mengclaster balita yang mengalami gizi buruk menjadi 2 cluster yaitu cluster tinggi dan cluster rendah. Penelitian ini diharapkan dapat membantu Pemerintahan dalam hal gizi balita di Indonesia. Penulis memilih menggunakan metode $K$-mean ialah karena dari penelitian-panelitian terdahulu mengatakan metode $K$-means mampu bekerja dengan baik dalam mengelompokkan data dalam skala kecil maupun skala besar dengan hasil yang akurat.

Tabel 1. Penelitian Terkait

\begin{tabular}{|c|c|c|c|}
\hline No & Judul & Penulis & Resume \\
\hline 1 & $\begin{array}{lr}\text { Penerapan } & \text { fuzzy } K- \\
\text { Nearest } & \text { Neighbor } \\
\text { (FK-NN) } & \text { Dalam } \\
\text { menentukan } & \text { status } \\
\text { gizi balita } & \end{array}$ & $\begin{array}{l}\text { Nugraha, S. } \\
\text { D., } \\
\text { Regasari, R., } \\
\text { Putri, M., } \\
\text { Wihandika, R. } \\
\text { C [1]. }\end{array}$ & $\begin{array}{l}\text { Berdasarkan penelitian yang dilakukan dapat disimpulkan } \\
\text { vgizi buruk adalah keadaan kurang gizi yang disebabkan } \\
\text { karena kekurangan asuran energi dan protein juga } \\
\text { mikronutrien dalam jangka waktu lama. }\end{array}$ \\
\hline 2 & $\begin{array}{l}\text { Implementasi } \\
\text { Algoritma K-Means } \\
\text { untuk pemetaan } \\
\text { Produktivitas panen } \\
\text { padi di Kabupaten } \\
\text { Karawang }\end{array}$ & $\begin{array}{l}\text { M. Rosyid } \\
\text { Ridlo, } \\
\text { Sofi Defiyanti, } \\
\text { Aji Primajaya } \\
\text { [3]. }\end{array}$ & $\begin{array}{l}\text { Berdasarkan penelitian yang dilakukan dapat disimpulkan } \\
\text { bahwa Produktivitas padi di Kabupaten Karawang dapat } \\
\text { dipetakan menggunakan teknik pengelompokkan data mining } \\
\text { menjadi } 3 \text { kelompok, yang terdiri dari Produktivitas panen } \\
\text { melebihi target, sesuai target dan kurang target dengan } \\
\text { persentase kenaikan target yang ditetapkan oleh dinas } \\
\text { pertanian Provinsi Jawa Barat sebesar 3\%. }\end{array}$ \\
\hline 3 & $\begin{array}{l}\text { Analisis cluster } \\
\text { dengan menggunakan } \\
\text { metode single linkage } \\
\text { dan metode } K \text {-means }\end{array}$ & $\begin{array}{l}\text { Rezki } \\
\text { Wahyuni, } \\
\text { Sigit Nugroho, } \\
\text { Pepi Novianti } \\
\text { [4]. }\end{array}$ & $\begin{array}{l}\text { Berdasarkan penelitian yang dilakukan dapat disimpulkan } \\
\text { bahwa pengclasteran yang dilakukan dengan menggunakan } \\
\text { tiga data yang berbeda yaitu Produksi, Produktivitas dan luas } \\
\text { tanaman Sayuran ini menghasilkan pemecahan cluster yang } \\
\text { berbeda antara metode single linkage dan metode K-means. }\end{array}$ \\
\hline
\end{tabular}

\section{METODE PENELITIAN}

\subsection{Data Mining}

Data mining adalah proses yang menggunakan teknik statistik, matematika, kecerdasan buatan, dan machine learning untuk mengekstraksi dan mengidentifikasi informasi yang bermanfaat dan pengetahuan yang terkait dari database yang besar [2].

Data mining adalah proses yang mempekerjakan satu atau lebih teknik pembelajaran computer (machinelearning) untuk menganalisis dan mengekstraksi pengetahuan (knowledge) secara otomatis [5].

\subsection{Metode K-Means}

Algoritma K-Means merupakan metode clustering nonhierarki yang memiliki waktu komputasi yang relatif cepat. Berdasarkan analisis perbandingan antara K-Means dan Fuzzy C-Means (FCM) yang dilakukan oleh (Suomi G. dan Sanjay Kumar D), didapatkan hasil yang membuktikan bahwa algoritme K-Means lebih cepat dengan 
elapsed time 0.433755 detik dibandingkan dengan algoritma FCM yang memiliki elapsedtime sebesar 0.781679 detik [6]. Algoritma K-Means merupakan algoritma yang relatif sederhana untuk mengklasifikasikan atau mengelompokkan sejumlah besar obyek dengan atribut tertentu ke dalam kelompok-kelompok (cluster) sebanyak K. Pada algoritma K-Means, jumlah klaster K sudah ditentukan lebih dahulu [7].

Algoritma K-Means merupakan salah satu algoritma partitional, karena K-Means didasarkan pada penentuan jumlah awal kelompok dengan mendefinisikan nilai centroid awalnya. Algoritma $K$-means menggunakan proses secara berulang untuk mendapatkan basis data cluster. Untuk mendapatkannya, dibutuhkan jumlah cluster awal yang diinginkan sebagai masukan dan penghasil jumlah cluster akhir sebagai output.

Langkah-angkah algoritma K-Means adalah sebagai berikut:

1. Tentukan Jumlah Kluster k.

2. Menentukan Titik pusat awal dari setiap kluster

3. Alokasikan semua data/objek ke kluster terdekat. Kedekatan dua objek ditentukan berdasarkan jarak kedua objek tersebut. Demikian juga kedekatan suatu data ke kluster tertentu ditentukan jarak antara data dengan pusat cluster. Dalam tahap ini perlu dihitung jarak tiap data ke tiap pusat kluster. Jarak paling antara satu data dengan satu kluster tertentu akan menentukan suatu data masuk dalam kluster mana. Untuk menghiutng jarak semua data ke setiap tiitk pusat kluster dapat menggunakan teori jarak Euclidean yang dirumuskan sebagai berikut:

4. $\mathrm{D}(\mathrm{x}, \mathrm{y})=\sqrt{\left(\mathrm{X}^{1}-Y^{1}\right)^{2}+\left(\mathrm{X}^{2}-\mathrm{Y}^{2}\right)^{2}}$

5. Hitung kembali pusat kluster dengan keanggotaan cluster yang sekarang. Pusat cluster adalah rata-rata dari semua data/objek dalam cluster tertentu. Jika dikehendaki bisa juga menggunakan median dari kluster tersebut. Jadi rata-rata (mean) bukan satu-satunya ukuran yang bisa dipakai.

6. Tugaskan lagi setiap objek memakai pusat kluster yang baru. Jika pusat cluster tidak berubah lagi maka proses klustering selesai. Atau, kembali ke langkah nomor 3 sampai pusat kluster tidak berubah lagi [8].

\subsection{RapidMiner}

RapidMiner merupakan perangkat lunak yang di dibuat untuk memudahkan pengguna dalam menggunakan perangkat lunak ini. Hasil yang diperlihatkan RapidMiner pun dapat ditampilkan secara visual dengan grafik, Menjadikan RapidMiner adalah salah satu software pilihan untuk melakukan ekstraksi data dengan metode-metode data mining [9].

\subsection{Diagram Aktivitas Kerja Penelitian}

Berikut ini alur diagram aktivitas kerja penelitian yang akan dilakukan pada penelitian ini :

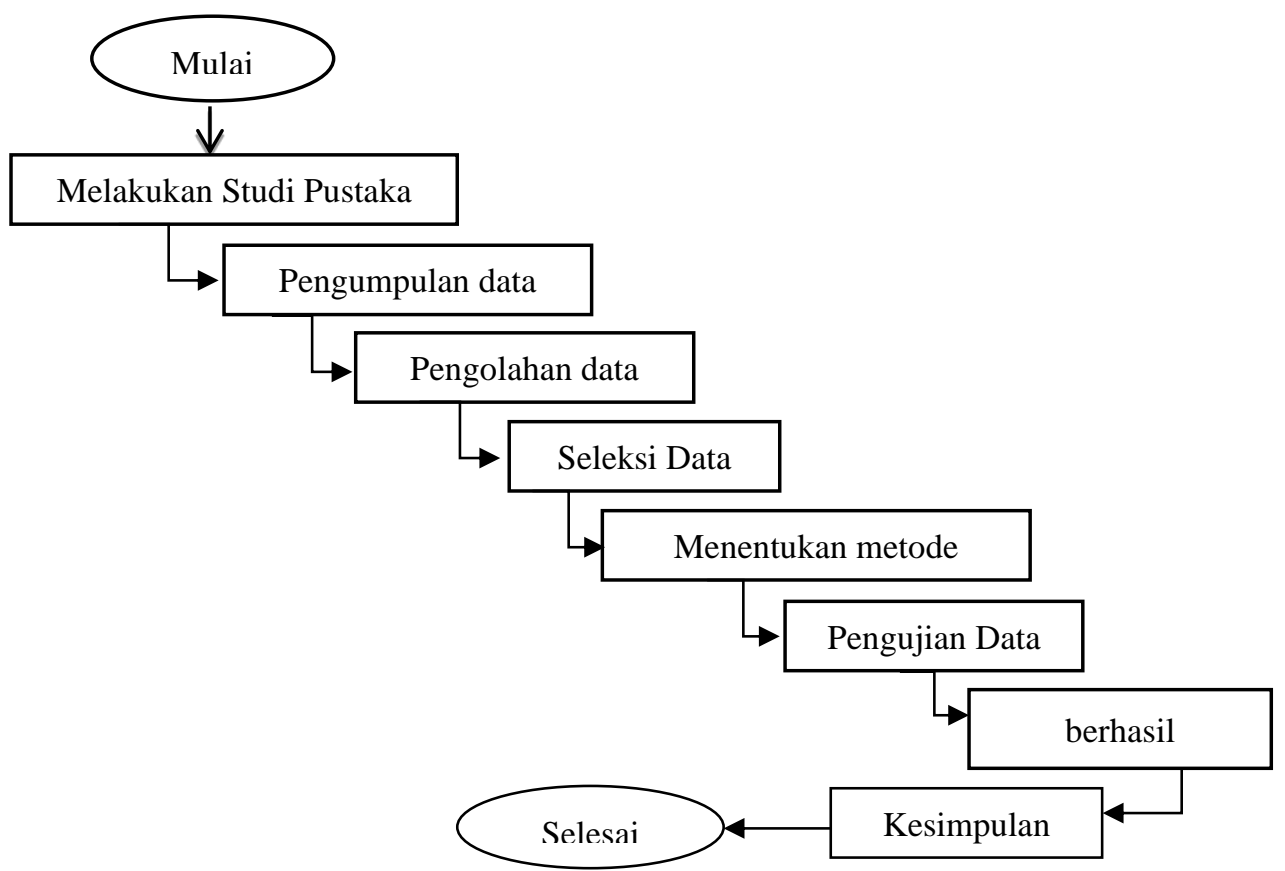

Gambar 1. Aktivitas Kerja Penelitian 
Pada gambar 1 diatas dapat dijelaskan dengan dengan beberapa urutan yaitu:

1. Pertama hal yang dilakukan adalah melakukan studi pustaka yang berkaitan dengan penelitian-penelitian sebelumnya tentang penggunaan metode $K$-means, serta untuk menguatkan penelitian ini berdasarkan teori yang digunakan.

2. Setelah melakukan studi pustaka tahap selanjutnya adalah menentukan metode yang sesuai untuk digunakan dalam teknik pengelompokkan (cluster), setelah melakukan pengamatan dan observasi penelitian memilih metode $K$-means.

3. Pada tahap ini peneliti melakukan pengumpulan data dan ini merupakan tahapan yang penting karena dapat berpengaruh terhadap hasil penelitian, sehingga dalam mengumpulkan data harus dilakukan dengan benar.

4. Tahap ini dilakukan seleksi terhadap data telah didapat. Karena data yang diperoleh semuanya digunakan, dan sesuai dengan atribut atau variabel yang dibutuhkan dalam penelitian dengan melakukan pengelompokkan data sehingga menjadi dataset.

5. Setelah semua data yang diperlukan telah dipilih, maka tahap penelitian selanjutnya adalah pengolahan data. Pada tahap ini akan dilakukan tranformasi atau mengubah nilai atribut data ke dalam bentuk data yang sesuai agar data dapat diproses menggunakan metode $K$-means.

6. Pada tahap pengujian hasil akan dilakukan pengujian data baik secara manual dengan metode $K$-means dan menggunakan software rapidminer.

7. Berdasarkan hasil pengujian maka dapat ditarik kesimpulan yang mengacu pada rumusan masalah dan tujuan penelitian. Saran yang digunakan untuk mengembangkan penelitian selanjutnya serta dimasukkan untuk meningkatkan kualitas penelitian.

\subsection{Pemodelan Metode K-Means}

Metode K-means merupakan algoritma yang relatif sederhana untuk mengclasifikasikan atau mengelompokkan sejumlah besar objek dengan atribut tertentu kedalam kelompok-kelompok sebanyak K. $K$-menas salah satu metode data clustering non hirarki yang berusaha mempartisi data yang ada di dalam bentuk satu atau lebih cluster atau kelompok.

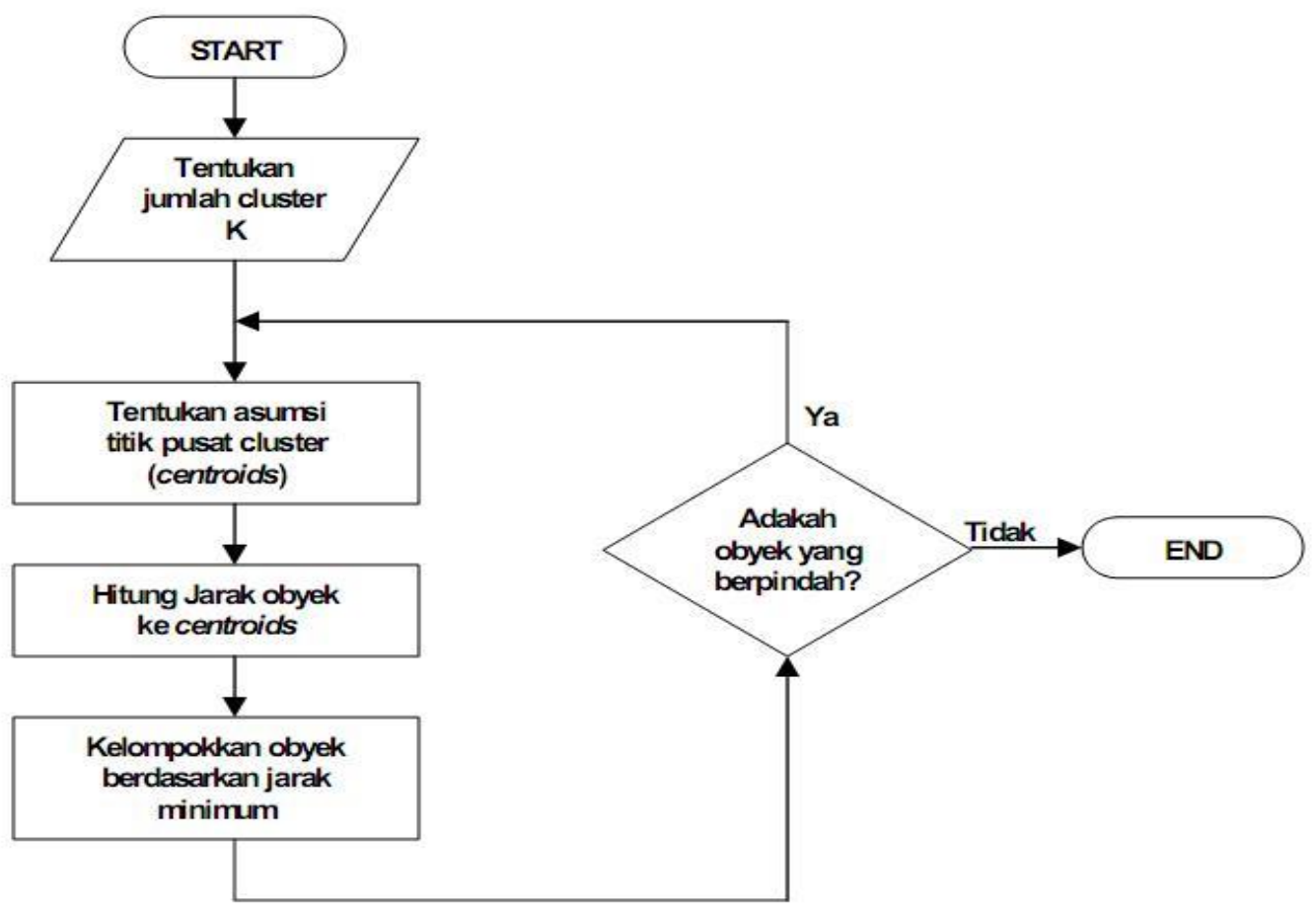

Gambar 2. Flowchart Metode K-Means

\section{HASIL DAN ANALISIS}

Hasil dan pembahasan pada bagian ini disajikan sesuai penelitian yang dilakukan. Pada penelitian ini digunakan Tools Rapidminer 5.3. sebagai pengujian data yang di analisa. Berikut merupakan penjelasan Implementasi $k$-means pada data balita yang mengalami gizi buruk usia 0-59 bulan. 


\subsection{Analisis Data Manual K-Means}

Data penelitian terdiri dari 34 provinsi yang terdiri dari tahun 2016-2018 seperti yang tertera pada tabel 3.1.

Selanjutnya masuk dalam tahap perhitungan menggunakan metode $k$-means:

1. Penentuan Pusat Cluster Awal

Penentuan titik cluster ini dilakukan dengan mengambil nilai terbesar (maksimum) untuk cluster tertinggi (C1), nilai terkecil untuk cluster rendah $(\mathrm{C} 2)$ sebagai berikut:

Tabel 2. Pusat Cluster Awal

\begin{tabular}{llll} 
Cluster & 2016 & 2017 & 2018 \\
\hline $\mathrm{C} 1$ & 6,91 & 7,40 & 7,40 \\
$\mathrm{C} 2$ & 0,98 & 2,00 & 2,00 \\
\hline
\end{tabular}

2. Perhitungan Jarak Cluster

Untuk menghitung jarak antara data dengan pusat cluster memakai persamaan (1) :

$\mathrm{C}_{\mathrm{aceh},} \mathrm{C}_{1}=\sqrt{(2,55-6,91)^{2}+(5,90-7,40)^{2}+(6,70-7,40)^{2}}=5,081004$

$\mathrm{C}_{\text {SumateraUtara, }} \mathrm{C}_{1}=\sqrt{(3,07-6,91)^{2}+(5,30-7,40)^{2}+(5,40-7,40)^{2}}=5,043709$

$\mathrm{C}_{\text {SumateraBarat, }} \mathrm{C}_{1}=\sqrt{(2,13-6,91)^{2}+(3,30-7,40)^{2}+(3,50-7,40)^{2}}=7,4974$

$\mathrm{C}_{\text {Riau, }} \mathrm{C}_{1}=\sqrt{(1,96-6,91)^{2}+(4,20-7,40)^{2}+(4,30-7,40)^{2}}=6,829766$

$\mathrm{C}_{\text {Jambi, }} \mathrm{C}_{1}=\sqrt{(2,38-6,91)^{2}+(3,00-7,40)^{2}+(3,80-7,40)^{2}}=7,364272$

Dan untuk cluster $\mathrm{C} 2$ adalah :

$\mathrm{C}_{\text {Aceh, }} \mathrm{C}_{2}=\sqrt{(2,55-0,98)^{2}+(5,90-2,00)^{2}+(6,70-2,00)^{2}}=6,944847$

$\mathrm{C}_{\text {SumateraUtara, }} \mathrm{C}_{2}=\sqrt{(3,07-0,98)^{2}+(5,30-2,00)^{2}+(5,40-2,00)^{2}}=5,618834$

$\mathrm{C}_{\text {SumateraBarat },} \mathrm{C}_{2}=\sqrt{(2,13-0,98)^{2}+(3,30-2,00)^{2}+(3,50-2,00)^{2}}=2,838538$

$\mathrm{C}_{\text {Riau, }} \mathrm{C}_{2}=\sqrt{(1,96-0,98)^{2}+(4,20-2,00)^{2}+(4,30-2,00)^{2}}=3,982964$

$\mathrm{C}_{\mathrm{Jambi},} \mathrm{C}_{2}=\sqrt{(2,38-0,98)^{2}+(3,00-2,00)^{2}+(3,80-2,00)^{2}}=3,01609$

Berikut ini adalah hasil dari perhitungan jarak cluster:

\begin{tabular}{lccccc}
\multicolumn{1}{c}{ PROVINSI } & Tabel 3. & Hasil Iterasi 1 & & & \\
& TINGGI & RENDAH & JARAK & C1 & C2 \\
\hline Aceh & 5,081004 & 6,944847 & 5,081004 & 1 & \\
Sumatera Utara & 5,043709 & 5,618834 & 5,043709 & 1 & \\
Sumatera Barat & 7,4974 & 2,838538 & 2,838538 & & 1 \\
Riau & 6,829766 & 3,982964 & 3,982964 & & 1 \\
Jambi & 7,364272 & 3,01609 & 3,01609 & & 1 \\
Sumatera Selatan & 7,877246 & 3,9219 & 3,9219 & & 1 \\
Bengkulu & 8,950536 & 1,972917 & 1,972917 & & 1 \\
Lampung & 7,938451 & 2,623223 & 2,623223 & & 1 \\
Kep. Bangka Belitung & 7,420391 & 2,957448 & 2,957448 & & 1 \\
Kep. Riau & 6,825907 & 2,986855 & 2,986855 & & 1 \\
Dki Jakarta & 7,749852 & 1,929378 & 1,929378 & & 1 \\
Jawa Barat & 8,020511 & 1,885975 & 1,885975 & & 1 \\
Jawa Tengah & 7,308386 & 2,54063 & 2,54063 & & 1 \\
Di Yogyakarta & 8,51693 & 1,574929 & 1,574929 & & 1 \\
Jawa Timur & 7,042989 & 2,835842 & 2,835842 & & 1 \\
Banten & 5,701026 & 3,985223 & 3,985223 & & 1 \\
Bali & 9,720314 & 1,442498 & 1,442498 & & 1 \\
Nusa Tenggara Barat & 5,460266 & 5,526011 & 5,460266 & 1 & \\
Nusa Tenggara Timur & 0,626259 & 9,654559 & 0,626259 & 1 & \\
Kalimantan Barat & 2,065672 & 7,737396 & 2,065672 & 1 & \\
Kalimantan Tengah & 2,647754 & 7,053574 & 2,647754 & 1 & \\
Kalimantan Selatan & 4,558969 & 5,617695 & 4,558969 & 1 & \\
Kalimantan Timur & 5,995081 & 3,717701 & 3,717701 & & 1 \\
Kalimantan Utara & 6,311814 & 3,542781 & 3,542781 & & 1 \\
Sulawesi Utara & 7,81796 & 3,538474 & 3,538474 & & 1 \\
Sulawesi Tengah & 3,413517 & 6,421246 & 3,413517 & 1 & \\
Sulawesi Selatan & 4,170635 & 5,51856 & 4,170635 & 1 & \\
Sulawesi Tenggara & 5,581093 & 6,449566 & 5,581093 & 1 & \\
& & & & &
\end{tabular}




\begin{tabular}{lccccc}
\multicolumn{1}{c}{ PROVINSI } & TINGGI & RENDAH & JARAK & C1 & C2 \\
\hline Gorontalo & 3,204138 & 7,498186 & 3,204138 & 1 & \\
Sulawesi Barat & 3,491661 & 6,778938 & 3,491661 & 1 & \\
Maluku & 2,181765 & 8,46501 & 2,181765 & 1 & \\
Maluku Utara & 6,630694 & 5,078819 & 5,078819 & & 1 \\
Papua Barat & 2,661672 & 7,158128 & 2,661672 & 1 & \\
Papua & 4,630821 & 6,434812 & 4,630821 & 1 & \\
\hline
\end{tabular}

Berdasarkan matrik yang didapatkan pada tabel di atas maka didapatkan pengelompokkan sebagai berikut :

$\mathrm{C} 1=1,2,18,19,20,21,22,26,27,28,29,30,31,33,34$

$\mathrm{C} 2=3,4,5,6,7,8,9,10,11,12,13,14,15,16,17,23,24,25,32$

3. Penentuan Pusat Cluster Baru

Setelah didapatkan hasil dari setiap cluster kemudian pusat cluster baru dihitung berdasarkan data member tiaptiap cluster yang sudah didapatkan memakai rumus yang sesuai dengan pusat member cluster. Berikut adalah pusat cluster untuk iterasi 2:

Tabel 4. Pusat Cluster Baru

\begin{tabular}{lccc} 
Cluster & 2016 & 2017 & 2018 \\
\hline C1 & 4,5573 & 5,8466 & 5,8133 \\
C2 & 2,4752 & 3,2421 & 3,3578 \\
\hline
\end{tabular}

Perhitungan Iterasi 2:

$$
\begin{aligned}
& C_{\text {aceh, }} C_{1}=\sqrt{(2,55-4,5573)^{2}+(5,90-5,8466)^{2}+(6,70-5,8133)^{2}}=3,904255 \\
& C_{\text {SumateraUtara, }} C_{1}=\sqrt{(3,07-4,5573)^{2}+(5,30-5,8466)^{2}+(5,40-5,8133)^{2}}=2,92144 \\
& C_{\text {SumateraBarat, }} C_{1}=\sqrt{(2,13-4,5573)^{2}+(3,30-5,8466)^{2}+(3,50-5,8133)^{2}}=4,601131 \\
& C_{\text {Riau, }} C_{1}=\sqrt{(1,96-4,5573)^{2}+(4,20-5,8466)^{2}+(4,30-5,8133)^{2}}=4,198322 \\
& C_{\text {Jambi, }} C_{1}=\sqrt{(2,38-4,5573)^{2}+(3,00-5,8466)^{2}+(3,80-5,8133)^{2}}=4,523808 \\
& \text { Dan untuk cluster C2 adalah: } \\
& C_{\text {aceh, }} C_{2}=\sqrt{(2,55-2,4752)^{2}+(5,90-3,2421)^{2}+(6,70-3,3578)^{2}}=5,056234 \\
& C_{\text {SumateraUtara, }} C_{2}=\sqrt{(3,07-2,4752)^{2}+(5,30-3,2421)^{2}+(5,40-3,3578)^{2}}=3,587743 \\
& C_{\text {SumateraBarat }} C_{2}=\sqrt{(2,13-2,4752)^{2}+(3,30-3,2421)^{2}+(3,50-3,3578)^{2}}=1,600363 \\
& C_{\text {Riau, }} C_{2}=\sqrt{(1,96-2,4752)^{2}+(4,20-3,2421)^{2}+(4,30-3,3578)^{2}}=2,490248 \\
& C_{\text {Jambi, }} C_{2}=\sqrt{(2,38-2,4752)^{2}+(3,00-3,2421)^{2}+(3,80-3,3578)^{2}}=1,664278
\end{aligned}
$$

Berikut adalah hasil dari perhitungan jarak cluster iterasi 2:

Tabel 5. Hasil Perhitungan Iterasi 2

\begin{tabular}{lrrrrr}
\multicolumn{1}{c}{ PROVINSI } & TINGGI & RENDAH & JARAK & C1 & C2 \\
\hline Aceh & 3,904255 & 5,056234 & 3,904255 & 1 & \\
Sumatera Utara & 2,92144 & 3,587743 & 2,92144 & 1 & \\
Sumatera Barat & 4,601131 & 1,600363 & 1,600363 & & 1 \\
Riau & 4,198322 & 2,490248 & 2,490248 & & 1 \\
Jambi & 4,523808 & 1,664278 & 1,664278 & & 1 \\
Sumatera Selatan & 5,406959 & 3,036879 & 3,036879 & & 1 \\
Bengkulu & 6,003103 & 2,28647 & 2,28647 & & 1 \\
Lampung & 5,013077 & 1,855378 & 1,855378 & & 1 \\
Kep. Bangka Belitung & 4,518068 & 1,697535 & 1,697535 & & 1 \\
Kep. Riau & 3,779701 & 0,849895 & 0,849895 & & 1 \\
Dki Jakarta & 4,601117 & 0,474003 & 0,474003 & & 1 \\
Jawa Barat & 4,950624 & 1,071656 & 1,071656 & & 1 \\
Jawa Tengah & 4,2726 & 0,76923 & 0,76923 & & 1 \\
Di Yogyakarta & 5,468178 & 1,513953 & 1,513953 & & 1 \\
Jawa Timur & 4,035167 & 0,892878 & 0,892878 & & 1 \\
Banten & 2,608073 & 1,617884 & 1,617884 & & 1 \\
Bali & 6,68565 & 2,724534 & 2,724534 & & 1 \\
Nusa Tenggara Barat & 3,463761 & 3,600297 & 3,463761 & 1 & \\
Nusa Tenggara Timur & 3,337326 & 7,29271 & 3,337326 & 1 &
\end{tabular}




\begin{tabular}{lrrrrr}
\multicolumn{1}{c}{ PROVINSI } & TINGGI & RENDAH & JARAK & C1 & C2 \\
\hline Kalimantan Barat & 1,254489 & 5,385918 & 1,254489 & 1 & \\
Kalimantan Tengah & 0,968922 & 4,69135 & 0,968922 & 1 & \\
Kalimantan Selatan & 2,326516 & 3,395422 & 2,326516 & 1 & \\
Kalimantan Timur & 2,847878 & 1,426813 & 1,426813 & & 1 \\
Kalimantan Utara & 3,083311 & 1,447431 & 1,447431 & & 1 \\
Sulawesi Utara & 5,177185 & 2,670409 & 2,670409 & & 1 \\
Sulawesi Tengah & 0,919371 & 4,104882 & 0,919371 & 1 & \\
Sulawesi Selatan & 1,255339 & 3,150697 & 1,255339 & 1 & \\
Sulawesi Tenggara & 3,959378 & 4,699835 & 3,959378 & 1 & \\
Gorontalo & 2,59341 & 5,25926 & 2,59341 & 1 & \\
Sulawesi Barat & 2,12864 & 4,495187 & 2,12864 & 1 & \\
Maluku & 2,849171 & 6,146265 & 2,849171 & 1 & \\
Maluku Utara & 4,499427 & 3,595414 & 3,595414 & & 1 \\
Papua Barat & 0,948354 & 4,825124 & 0,948354 & 1 & \\
Papua & 2,852679 & 4,424873 & 2,852679 & 1 & \\
\hline
\end{tabular}

Berdasarkan matrik yang didapatkan pada tabel di atas maka didapatkan pengelompokkan sebagai berikut:

$\mathrm{C} 1=1,2,18,19,20,21,22,26,27,28,29,30,31,33,34$

$\mathrm{C} 2=3,4,5,6,7,8,9,10,11,12,13,14,15,16,17,23,24,25,32$

Dari hasil iterasi 2 dapat dilihat bahwa hasil yang diperoleh sama dengan iterasi 1 maka perhitungan dihentikan sampai iterasi 2. Untuk provinai pada cluster C1(tertinggi) ada 15 Provinsi yaitu (Aceh, Sumatera Utara, Nusa Tenggara Barat, Nusa Tenggara Timur, Kalimantan Barat, kalimantan Tengah, Kalimantan Selatan, Sulawesi Tengah, Sulawesi Selatan, Sulawesi Tenggara, Sulawesi Tenggara, Gorontalo, Sulawesi Barat, Papua Barat, Papua). Untuk provinsi pada cluster C2(rendah) ada 19 yaitu (Sumatera Barat, Riau, Jambi, Sumatera Selatan, Bengkulu, Lampung, Kep. Bangka Belitung, Kep. Riau, Dki Jakarta, Jawa Barat, Jawa Tengah, DI Yogyakarta, Jawa Timur, Banten, Bali, Kalimantan Timur, Kalimantan Utara, Sulawesi utara, Maluku Utara).

\subsection{Pemodelan RapidMiner}

Pada penelitian ini digunakan tools rapidminer sebagai pengujian data yang telah di analisa. Berikut adalah bagian-bagian dari rapidminer beserta isi dari data yang dibuat.

1. Input Sistem

Berikut adalah penjelasan cara memasukkan data baru yang akan dieksekusi lebih lanjut, pada hal ini data yang akan di eksekusi berupa data excel. Tahapan dapat dilihat pada gambar dibawah ini.

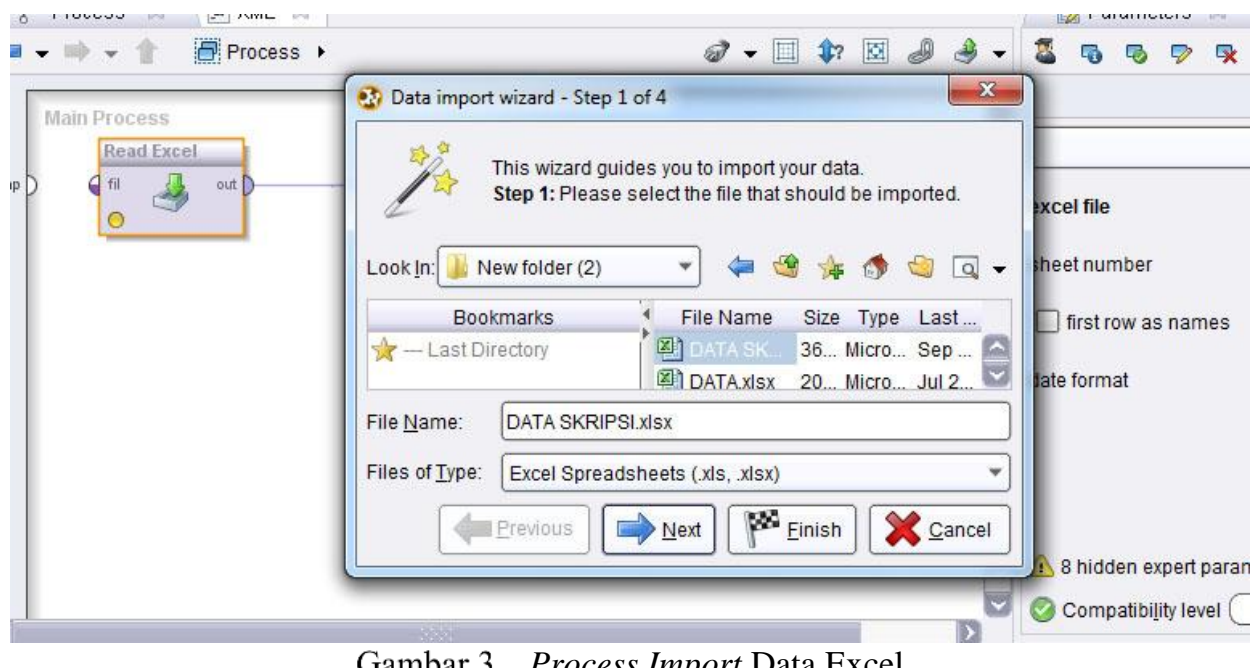

Gambar 3. Process Import Data Excel

Untuk menginputkan data excel dapat menggunakan dua cara yaitu melalui bagian filter dengan mengetikkan read excel atau dapat melalui bagian repositories lalu Import Excel Sheet. Pada bagian look in kita dapat mencari dimana letak file data excel yang kita simpan. Seperti pada gambar, data disimpan dalam folder data dengan nama data seperti yang tertera pada gambar. Selanjutnya akan muncul tampilan seperti gambar 4 : 


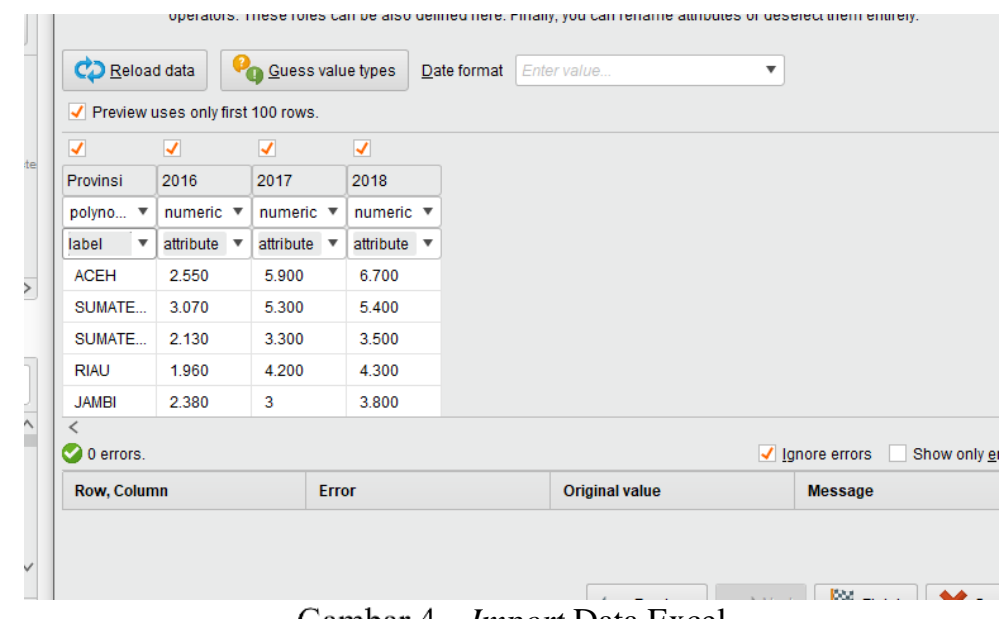

Gambar 4. Import Data Excel

Pada ini dilakukan pemilihan tipe data dimana pada tahap ini memilih bagian yang akan diberi tipe "label" yang akan menjadi penentu dari dibentuknya pengelompokan.

\section{Proses Sistem}

Lakukan drag and drop data yang dipilih kedalam view process. Berikut alur proses import data yang dilakukan.

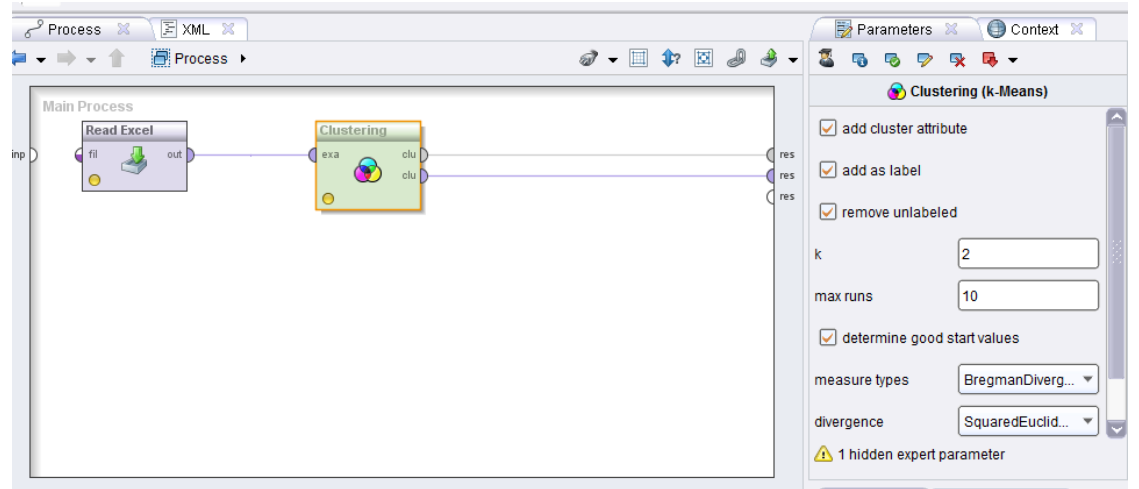

Gambar 5. Proses Sistem

Setelah data yang dipilih didrag kedalam main process, selanjutnya pada bagian filter ketikkan $k$-means. Maka akan muncul operator $k$-means lalu pilih dan drag kedalam halaman main process. Selanjutnya hubungkan data read excel dengan operator $k$-means lalu klik tools run.

\section{Output Sistem}

Setelah melakukan proses sistem seperti yang tertera pada gambar 5 maka akan muncul hasil dari rapidminer yang dapat dilihat pada gambar 6, dimana cluster 0 adalah cluster tinggi dan cluster 1 adalah cluster rendah. 


\begin{tabular}{|l|l|l|l|l|l|l|}
\hline Row No. & id & Provinsi & cluster & $\mathbf{2 0 1 6}$ & $\mathbf{2 0 1 7}$ & $\mathbf{2 0 1 8}$ \\
\hline 1 & 1 & ACEH & cluster_0 & 2.550 & 5.900 & 6.700 \\
\hline 2 & 2 & SUMATERA $\ldots$ & cluster_0 & 3.070 & 5.300 & 5.400 \\
\hline 3 & 3 & SUMATERA B... & cluster_1 & 2.130 & 3.300 & 3.500 \\
\hline 4 & 4 & RIAU & cluster_1 & 1.960 & 4.200 & 4.300 \\
\hline 5 & 5 & JAMBI & cluster_1 & 2.380 & 3 & 3.800 \\
\hline 6 & 6 & SUMATERA S... & cluster_1 & 1.930 & 2.100 & 4.900 \\
\hline 7 & 7 & BENGKULU & cluster_1 & 1.300 & 2.300 & 2.800 \\
\hline 8 & 8 & LAMPUNG & cluster_1 & 1.630 & 3.500 & 3.100 \\
\hline 9 & 10 & KEP. BANGK $\ldots$ & cluster_1 & 2.010 & 3.700 & 3.400 \\
\hline 10 & 11 & KEP. RIAU & cluster_1 & 3.730 & 3 & 3.200 \\
\hline 11 & 12 & DKI JAKARTA & cluster_1 & 2.990 & 3 & 2.300 \\
\hline 12 & 13 & JAWA BARAT & cluster_1 & 2.350 & 2.900 & 2.600 \\
\hline 13 & 14 & JAWA TENGAH & cluster_1 & 2.980 & 3 & 3.100 \\
\hline 14 & DI YOGYAKA $\ldots$ & cluster_1 & 2.100 & 2.400 & 2.500 \\
\hline
\end{tabular}

Gambar 6. Data Hasil Clustering

\section{KESIMPULAN}

Berdasarkan pembahasan sebelumnya dapat disimpulkan bahwa penerapan Data mining dengan menggunakan algoritma k-means pada pengelompokan balita yang memiliki gizi buruk menurut provinsi dapat diterapkan. Sumber data yang digunakan pada penelitian ini adalah data yang diperoleh dari BPS (Badan Pusat Statistik). Jumlah data yang digunakan sebanyak 34 provinsi yang terdiri dari tahun 2016-2018. Dari hasil pengelompokan diperoleh dua cluster yaitu tinggi dan renda. Cluster tinggi terdiri dari 15 provinsi dan cluster rendah terdiri dari 19 provinsi. Pengujian data pada Rapidminer 5.3 menggunakan algoritma k-means dapat menampilkan keakuratan data antara perhitungan manual dan sistem.

\section{UCAPAN TERIMA KASIH}

Penulis mengucapkan terima kasih pada STIKOM Tunas Bangsa Pematangsiantar dan pada pihak-pihak yang membantu penulis dalam menyelesaikan penelitian ini.

\section{REFERENSI}

[1] S. D. Nugraha, R. R. M. Putri, and R. C. Wihandika, "Penerapan Fuzzy K-Nearest Neighbor ( FK-NN ) Dalam Menentukan Status Gizi Balita," vol. 1, no. 9, pp. 925-932, 2017.

[2] A. N. Khomarudin, "Teknik Data Mining : Algoritma K-Means Clustering,” pp. 1-12, 2016.

[3] M. R. Ridlo, S. Defiyanti, and A. Primajaya, "Implementasi Algoritme K-Means Untuk Pemetaan Produktivitas Panen Padi Di Kabupaten Karawang,”pp. 426-433, 2017.

[4] R. Wahyuni, S. Nugroho, and P. Novianti, "Analisis Klaster Dengan Menggunakan Metode Single Linkage Dan Metode K-Means," pp. 1-9, 2015.

[5] Y. Warih, Eggy Inaidi Andana; Rahayu, "Penerapan Data Mining untuk Menentukan Estimasi Produktivitas Tanaman Tebu dengan Menggunakan Algoritma Linear Regresi Berganda di Kabupaten Rembang," Informatika, pp. 1-5, 2014.

[6] M. R. Ridlo, S. Defiyanti, A. Primajaya, M. Rosyid Ridlo, S. Defiyanti, and A. Primajaya, "Implementasi Algoritme K-Means Untuk Pemetaan Produktivitas Panen Padi Di Kabupaten Karawang," Citee 2017, pp. 426-433, 2017.

[7] E. Rivani, P. Pengkajian, P. Data, S. Jenderal, and D. P. R. Ri, "APLIKASI K- MEANS CLUSTER UNTUK PENGELOMPOKKAN PROVINSI BERDASARKAN PRODUKSI PADI , JAGUNG , KEDELAI , DAN KACANG HIJAU TAHUN 2009 Ukuran Similaritas,” vol. 10, no. 2, pp. 122-134, 2010.

[8] D. Triyansyah and D. Fitrianah, "Analisis Data Mining Menggunakan Algoritma K-Means Clustering Untuk Menentukan Strategi Marketing," no. September, 2018.

[9] T. Verma, "Tokenization and Filtering Process in RapidMiner," vol. 7, no. 2, pp. 16-18, 2014. 